\title{
Evaluation of DNA Recombinant Methodologies for the Diagnosis of Plasmodium falciparum and their Comparison with the Microscopy Assay
}

\author{
L Urdaneta $/{ }^{*}$, P Guevara/ ${ }^{+}$, JL Ramirez* \\ Escuela de Malariología y Saneamiento Ambiental “Dr. Arnoldo Gabaldón”, Maracay,Venezuela \\ *Grupo de Genética Molecular, Instituto de Biologia Experimental, Universidad Central de Venezuela, \\ Caracas, Venezuela
}

\begin{abstract}
Since 1984, DNA tests based on the highly repeated subtelomeric sequences of Plasmodium falciparum (rep 20) have been frequently used in malaria diagnosis. Rep 20 is very specific for this parasite, and is made of 21 bp units, organized in repeated blocks with direct and inverted orientation. Based in this particular organization, we selected a unique consensus oligonucleotide (pf-21) to drive a PCR reaction coupled to hybridization to non-radioactive labeled probes. The pf-21 unique oligo PCR (pf-21-I) assay produced DNA amplification fingerprints when was applied on purified $\mathrm{P}$. falciparum DNA samples (Brazil and Colombia), as well as in patient's blood samples from a large area of Venezuela. The performance of the Pf-21-I assay was compared against Giemsa stained thick blood smears from samples collected at a malaria endemic area of the Bolivar State, Venezuela, at the field station of Malariología in Tumeremo. Coupled to non-radioactive hybridization the pf-21-I performed better than the traditional microscopic method with a $r=1.7: 1$. In the case of mixed infections the $r$ value of $\mathrm{P}$. falciparum detection increased to 2.5:1. The increased diagnostic sensitivity of the test produced with this homologous oligonucleotide could provide an alternative to the epidemiological diagnosis of $\mathrm{P}$. falciparum being currently used in Venezuela endemic areas, where low parasitemia levels and asymptomatic malaria are frequent. In addition, the DNA fingerprint could be tested in molecular population studies.
\end{abstract}

Key words: Plasmodium falciparum - diagnosis - polymerase chain reaction - malaria

Plasmodium falciparum, the agent of the most lethal form of malaria, causes 1.5 to 2.7 million deaths each year, mostly among children. The incidence of malaria in the world is estimated to be 300-500 million clinical cases annually (WHO 1997). An approximate of 2,300 million people lived in areas with malaria risk, distributed in 100 endemic countries including Venezuela.

The Venezuela global incidence in 1997 was 28,056 malaria cases (Dirección de Endemias Rurales, Venezuelan Malaria Program, pers. commun.). Bolívar State located in the Amazon basin is responsible for $40-50 \%$ of the global inci-

Financial support from Escuela de Malariología y Saneamiento Ambiental "Dr. Arnoldo Gabaldón", Maracay-Venezuela, la Fundación para el Desarrollo de la Ciencia y la Tecnología de Aragua, Venezuela and Grupo de Genética Molecular del Instituto de Biología Experimental, Universidad Central de Venezuela, Venezuela.

${ }^{+}$Corresponding author: Fax: +58-2-753-5897. E-mail: pguevara@fred.fhcrc.org

Received 15 June 1998

Accepted 30 July 1998 dence for the whole country. The number of malaria cases has been in a constant rise during the previous years, due mainly to local economic activities (gold and diamond mines), changes in human migration patterns and a high prevalence of P. falciparum resistant malaria to chloroquine and pyrimethamine/sulfadoxine drugs.

Studies on epidemiology of parasitic infections, on measures to control disease and clinical evaluation of treatments, all require identification of the infecting species. The identification of malaria parasite is usually performed with traditional microscopic diagnosis of Giemsa-stained thick blood, which is inexpensive and of easy application in the field. Nevertheless, the sensitivity of microscopic method depends on highly trained examiners, is time-consuming when large numbers of samples must be examined, and is thus not the most appropriate method for large-scale epidemiological surveys.

Assay strategies have been proposed that directly detect abundant parasite nucleic acid sequences, including repetitive DNA (Franzen et al. 1984, Barker et al. 1986, Oquendo et al. 1986, McLaughlin et al. 1987, Zolg et al. 1987) or ribosomal RNA (rRNA) (Lal et al. 1989, Wathers \& McCutchan 1989). 
In the P. falciparum genome there are several repetitive sequences. One of these consists of 21bp blocks, imperfectly repeated in tandem clusters oriented in opposite directions (rep-20). These rep20 sequences are found in all chromosomes of the parasite (Oquendo et al. 1986). DNA probes directed to these repeats hybridize with $P$. falciparum strains from South America, Africa, and South and Southeast Asia (Buesing et al. 1987), and their sensitivity is comparable to that of conventional microscopy (Lanar et al. 1989). The sensitivity of DNA and RNA approaches have been further increased through the amplification of the target DNA using the polymerase chain reaction (PCR).

Considering the high specificity of the rep-20 for P. falciparum and its genomic organization, our objective was directed to design a diagnostic PCR assay coupled to non-radioactive hybridization, for the detection of $P$. falciparum in human blood samples. In the present communication we report this diagnostic assay using a single oligo and digoxigenin labeled probes detected by photoluminescence. Its application to blood samples obtained and processed in the endemic areas, compared to traditional thick smear technique is discussed. We also report the application of the assay to isolated $P$. falciparum DNA to produce amplification patterns differentiating strains of several geographical locations and proposing its use as a tool in molecular epidemiological studies.

\section{MATERIALS AND METHODS}

Blood samples collection and treatment - The sample blood was obtained from patients with malaria symptoms assisting to the malaria diagnostic post of the Venezuelan Malaria Program in Tumeremo, Bolívar State. The samples were collected during two visits of one week each to the endemic area during July 1993 and March 1994.

Duplicate samples of fingerprick blood were collected from 33 individuals in heparinized capillary tubes; $50 \mu \mathrm{l}$ were deposited in Wathman paper filter, dried at room temperature and stored in individual and labeled sealed plastic bag, in case it was necessary to repeat the PCR assay. Another $50 \mu \mathrm{l}$ were transferred to a $1.5 \mathrm{ml}$ centrifuge tube in which the P. falciparum DNA was isolated using the chelex-100-iron protocol (Wooden et al. 1993).

Microscopic examination - Two thick blood films were prepared for each patient during the blood collection process. The blood smears were stained with Giemsa, and one reading was performed at field site under routine conditions of work (100 fields examined under oil immersion optics before a slide was considered negative), by an expert microscopist at the diagnostic post of the
Malaria Program. For comparison purposes, a second microscopic diagnostic was done by one of us (L.U.); in this case, the sample was considered negative after 200 microscopic fields were examined. The parasite number was registered with respect to 200 white blood cells.

$P$. falciparum reference strain DNAs - P. falciparum reference strain DNAs were a gift of the following researchers: (1) one Colombian strain from Dr Moises Wasserman (Instituto Nacional de Higiene de Colombia), (2) 12 Brazilian isolates from Dr Hernan Del Portillo (Universidade de São Paulo, Brasil) and (3) 2 cultured strains from Dr Erlinda Sánchez (Universidad de Carabobo and Malariología, Venezuela). The parasite genomic DNA was extracted using proteinase $\mathrm{K}$, followed by phenol-chloroform extraction and ethanol precipitation.

Primers selection and PCR assays - Two oligonucleotides were designed: (1) a primer of 16 bp, pf-16 (5'-ACT AAC TTA GGT CTTA-3'), and (2) a primer of $21 \mathrm{bp} \mathrm{pf}-21$ (5'-ATG TTA GTC AAC TTA AGA CCT-3'), both derived from the pf-21 consensus sequence reported by Oquendo et al. (1986).

The $P$. falciparum assay described by Tirasophon et al. (1991), was included in this study as a reference test. This PCR uses primers K114-P1 (5'-CGC TAC ATA TGC TAG TTG CCA GAC3') and K114-P2 (5'-CGT GTA CCA TAC ATC CTA CCA AC-3') for amplification of a $206 \mathrm{bp}$ fragment and, primer K1-14 (5'-GCT ATA ACC ACT ATT GCA ACG-3') for hybridization. We designated the PCR assays I to III according to the oligonucleotid used: PCR I: pf-21 primer alone, PCR II: two primers pf-16 and pf-21, and PCR III: reference test using oligos K114-P1 and K114-P2.

$P C R$ reaction conditions - Amplification reaction mixtures consisted of $50 \mathrm{mM} \mathrm{KCL}, 10 \mathrm{mM}$ Tris HCL pH 8.8, $1 \%$ Triton X-100, 3mM dNTPs, and $3 \mathrm{mM} \mathrm{MgCl} 2$. Primers pf- 21 and pf- 16 were at $4 \mu \mathrm{M}$. Primers K114-P1 and K114-P2 were at 1 $\mu$ M. 1.25 units of Taq polymerase. The total volume was $25 \mu$ l. The specificity and sensitivity of the assays were tested against different $P$. falciparum DNA concentrations ( $200 \mathrm{ng} / \mu \mathrm{l}$ to 0.02 $\mathrm{pg} / \mu \mathrm{l})$, including in each case a negative control. Amplification products were analyzed by electrophoresis in 3\% agarose gels and detected by staining with ethidium bromide.

PCR I and PCR II initial denaturation was done at $94^{\circ} \mathrm{C}$ for $5 \mathrm{~min}$ followed by 35 cycles of $94^{\circ} \mathrm{C}$ for $1 \mathrm{~min}$, annealing at $40^{\circ} \mathrm{C}$ for $1 \mathrm{~min}$, and extension at $72^{\circ} \mathrm{C}$ for $2 \mathrm{~min}$, and a final elongation at $72^{\circ} \mathrm{C}$ for $5 \mathrm{~min}$.

PCR III initial denaturation at $94^{\circ} \mathrm{C}$ for $5 \mathrm{~min}$; 35 cycles of denaturation at $94^{\circ} \mathrm{C}$ for $1 \mathrm{~min}$, an- 
nealing at $60^{\circ} \mathrm{C}$ for $1 \mathrm{~min}$, and extension at $72^{\circ} \mathrm{C}$ for $1 \mathrm{~min}$, and a final elongation at $72^{\circ} \mathrm{C}$ for $5 \mathrm{~min}$.

Blots and DNA hybridizations - Amplified DNAs were size fractionated by electrophoresis in 3\% agarose gel and transferred onto nylon membranes (Hybond $\mathrm{N}+$, Amersham) using the VacuGene apparatus (Pharmacia LKB) following the manufacturer instructions. Slot blots were performed as described in Davis et al. (1986).

The filters were pre-hybridized in 2X SSC, 10X Denhardt's solution (Maniatis et al. 1982) and 1.5\% blocking reagent (Boehringer-Mannheim) for $1 \mathrm{hr}$ at $37^{\circ} \mathrm{C}$. The hybridization with digoxigenin labeled oligonucleotides were incubated for $2 \mathrm{hr}$ at $53^{\circ} \mathrm{C}$ for pf-21, and $50^{\circ} \mathrm{C}$ for $\mathrm{K} 1-14$. Filters were washed in $6 \mathrm{X} \mathrm{SSC}-1 \% \mathrm{SDS}$ at room temperature for 15 min, $2 \mathrm{X} \mathrm{SSC}-0.1 \%$ at room temperature for $15 \mathrm{~min}$, and finally $0.2 \mathrm{XSC}-0.1 \%$ SDS at $37^{\circ} \mathrm{C}$ for 15 min. In the case of DNA probes, the filters were pre-hybridized in 6X SSC, $5 \mathrm{X}$ Denhardt's, $0.5 \%$ SDS, $5 \%$ blocking reagent and $50 \%$ formamide for $2 \mathrm{hr}$ at $37^{\circ} \mathrm{C}$. The hybridizations with digoxigenin labeled amplified products pf-21 and $\mathrm{K} 114-\mathrm{P} 1 / \mathrm{K} 114-\mathrm{P} 2$ were incubated at $37^{\circ} \mathrm{C}$ for $12-$ $18 \mathrm{hr}$. Filters were washed every $15 \mathrm{~min}$ in $2 \mathrm{X}$ SSC$0.1 \%$ SDS at room temperature for $1 \mathrm{hr}, 1 \mathrm{X} \mathrm{SSC}-$ $0.1 \% \mathrm{SDS}$ at $68^{\circ} \mathrm{C}$ each $15 \mathrm{~min}$ for $1 \mathrm{hr}$, and $0.1 \mathrm{X}$ SSC- $0.1 \%$ SDS at $68^{\circ} \mathrm{C}$ twice each $15 \mathrm{~min}$. The maxim concentration used for both the oligonucleotides and the probes was $20 \mathrm{ng} / \mu \mathrm{l}$ of hybridization solution.

DNA probe labeling and detection - The Genius Kit from Boehringer-Mannheim was used for DNA labeling and detection by photoluminiscence. The oligonucleotides were labeled incorporating the dUTP-DGX using terminal transferase, following the manufacturer recommendations. The DNA probes were labeled by the multiprimer system incorporating the dUTP-DGX nucleotide. The photoluminescent substrate used was Lumi-phos 530 and the signals were detected using X-rays films.

\section{RESULTS}

PCR assays - Two PCR amplification systems were designed and standardized: PCR (I) pf-21 primer and PCR (II) pf-16+pf-21 primers. Both systems with target in the 21 bp repeat (rep 20). The reference system PCR (III) K114-P1/K114-P2 primers, was standardized to our conditions as described above. Fig. 1 shows the results of these amplification systems using DNA from two $P$. falciparum strains from Colombia. Both the PCR I and II directed to rep 20, yielded a broad range of amplified products, with band sizes from $200 \mathrm{bp}$ to $3 \mathrm{~Kb}$ (Fig. 1A, C; lanes 1, 2), with higher intensity in the PCR II system. Similar results were reported by Barker et al. (1992), using complemen- tary and degenerate primers directed against rep 20. Nevertheless, the use of two primers PCR II yielded nonspecific amplification with human DNA (Fig. 1C; lane 3) and negative control without DNA (Fig. 1C; lane 4). In the amplification with a single primer (PCR I) (Fig. 1A; lanes 1,2), a broad range of reproducible amplified products was observed, clearly showing a $344 \mathrm{bp}$ band for this $P$. falciparum isolate. No amplification was observed in the negative control (Fig. 1A; lanes 3, 4). The PCR III reference system yielded an expected single 206 bp band specific for $P$. falciparum (Fig. 1B; lanes 1, 2), without amplifying the human DNA (lane 3).

Considering the specificity and the amplification profile in P. falciparum DNA, the PCR I system was selected for detection of $P$. falciparum from field samples.

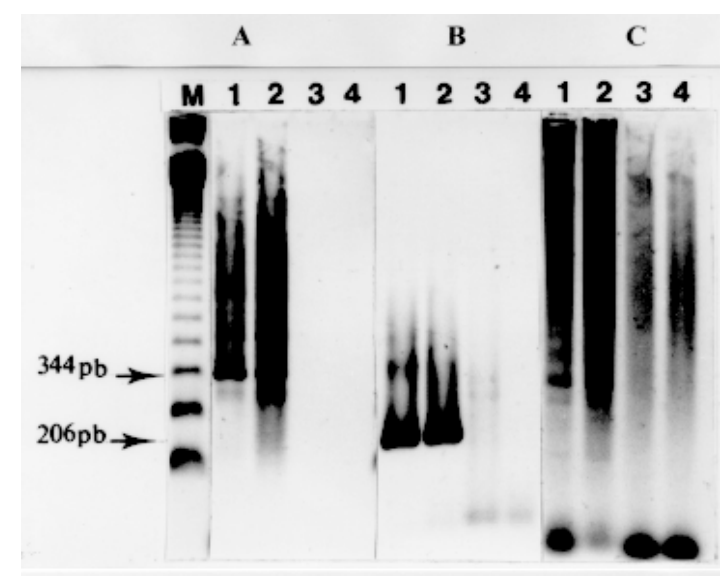

Fig. 1: PCR systems I, II and III. Electrophoresis in 3\% agarose gel of amplified products by the systems. A: PCR I pf-21; B: PCR III K114-P1/K114-P2; C: PCR II pf-21+pf-16. Lanes - 1: $200 \mathrm{ng}$ of Plasmodium falciparum purified DNA; 2: $50 \mathrm{ng}$ of $P$. falciparum purified DNA; 3: negative control with human DNA; 4: negative control without DNA; M, 123 bp ladder.

Sensitivity of PCR I and PCR III systems - Once the specificity of these systems was determined, experiments were done to examine the detection sensitivity of both systems against serial dilutions of purified $P$. falciparum DNA. Fig. 2 shows the results of amplification products in $3 \%$ agarose gel electrophoresis for PCR I (Fig. 2A), PCR III (Fig. 2B) and Southern PCR III hybridizations (Fig. 2C). Both systems showed a detection level of $0.2 \mathrm{pg}$ of $P$. falciparum DNA on agarose gels (Figs 2A, 2B; lane 7), equivalent to ten parasites. The South- 
ern hybridization tests with digoxigenin labeled probe, yielded the following results: (a) the PCR I hybridized to the pf-21 primer showed a sensitivity level lower than the one observed in the electrophoresis, suggesting problems with the hybridization conditions (results not shown); (b) the PCR III hybridization (Fig. 2C) showed an increase in the sensitivity to $0.02 \mathrm{pg}$ of DNA, equivalent to one parasite (Fig. 2C; lane 8).
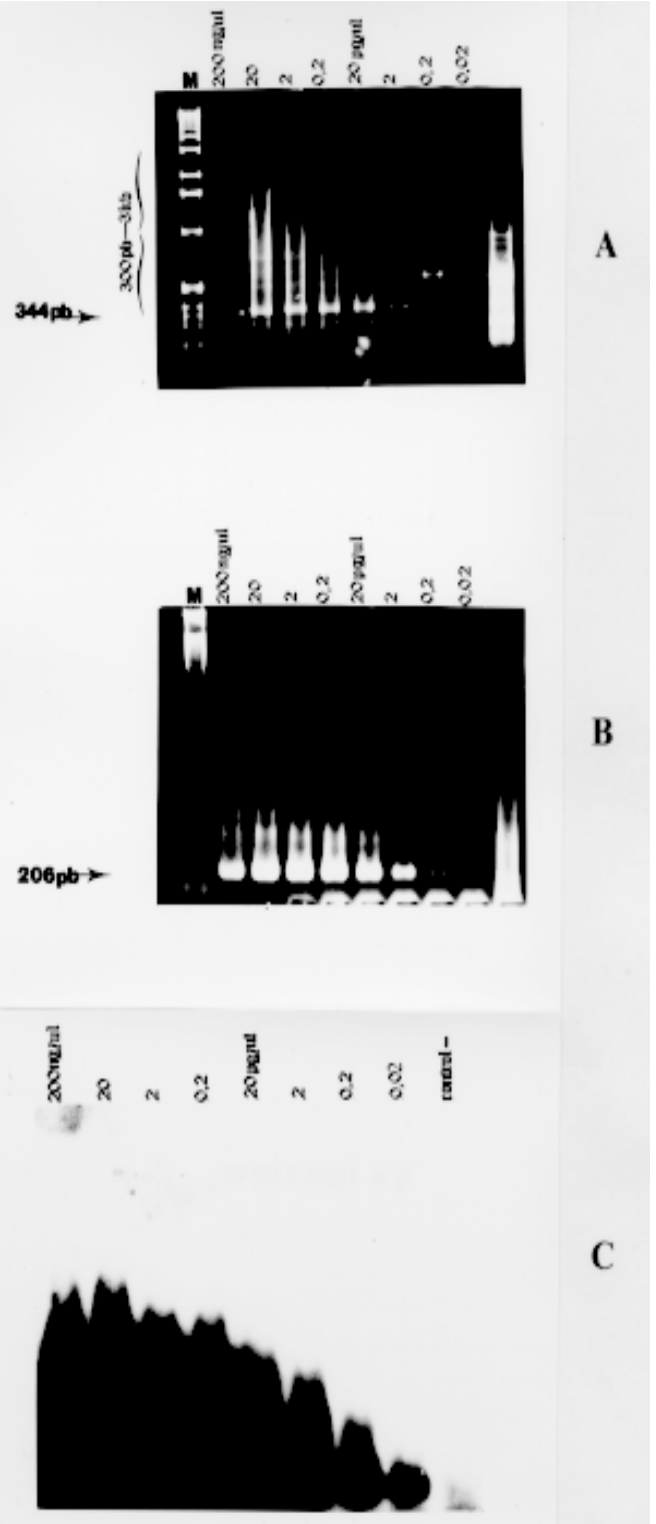

Fig. 2: sensitivity of PCR I and PCR II systems. Electrophoresis in 3\% agarose gel of amplified products from serial dilutions of Plasmodium falciparum purified DNA. A: PCR I system pf-21; B: PCR III system K114-P1/K114-P2; C: Southern-blot hybridization of $\mathrm{B}$ against capture $\mathrm{K}-14$ primer labeled with digoxigenin. The exposure time was $15 \mathrm{~min}$. Lanes - 1 : $200 \mathrm{ng} / \mu \mathrm{l} ; 2: 20 \mathrm{ng} / \mu \mathrm{l} ; 3: 2 \mathrm{ng} / \mu \mathrm{l} ; 4: 0.2 \mathrm{ng} / \mu \mathrm{l} ; 5: 20 \mathrm{pg} / \mu \mathrm{l} ; 6$ : $2 \mathrm{pg} / \mu \mathrm{l} ; 7: 0.2 \mathrm{pg} / \mu \mathrm{l} ; 8: 0.02 \mathrm{pg} / \mu \mathrm{l} ; \mathrm{M}$ - Fig. $2 \mathrm{~A}$ : ladder $1 \mathrm{~Kb}$; Fig. 2B: ladder $123 \mathrm{bp}$.
Effects of anticoagulants on the PCR assays Previous reports have revealed the inhibitory effect in PCR analysis of certain anticoagulants such as heparin (Barker et al. 1992, Tirasophon et al. 1991), citrate and EDTA (Tirasophon et al. 1994). We tested the PCR assay amplifying vertebrate rDNA included as a positive control for the PCR reaction (Premoli-de-Percoco et al. 1993), taking blood samples with different anticoagulants (heparin and citrate), including a sample in Wathman paper. The results showed the specific vertebrate's rDNA band of $126 \mathrm{bp}$ in all the samples, indicating that there is no inhibition by the anticoagulants (results not shown).

$P C R$ detection of $P$. falciparum DNA in human blood samples - Fig. 3 shows the agarose $2 \%$ electrophoresis of PCR III for a total of 32 samples. There is a $206 \mathrm{bp}$ band (positive signal) in 11 samples (Fig. 3A; lanes 1, 2, 6, 7, 8, 9, 10, 11; Fig. $3 \mathrm{~B}$; lanes $2,10,14)$. There was inhibition of the amplification reaction in one sample (Fig. 3B; lane 6) as revealed by the absence of the vertebrate's rDNA amplification band of $126 \mathrm{bp}$. The same samples were examined using the PCR I system, with the single pf-21 primer (Fig. 4). Those samples

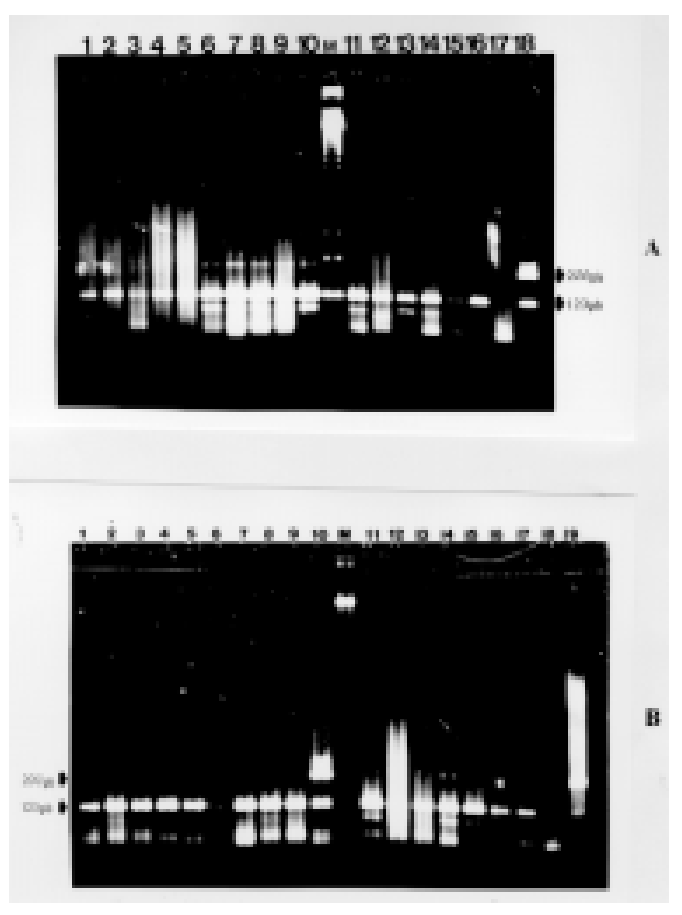

Fig. 3: PCR on human samples, PCR III system. Electrophoresis in $2 \%$ agarose gel of amplified products by PCR III. A: lanes 1 to 10 and 11 to 15 , human samples 1 to 15 ; lane 16 , negative control with human DNA; lane 17, negative control no DNA; lane 18, positive control with purified Plasmodium falciparum DNA. B: lanes 1 to 10 and 11 to 16 , human samples 17 to 32 ; lane 17, negative control with human DNA; lane 18, negative control no DNA; lane 19, positive control with purified $P$. falciparum DNA; M , 123 bp ladder. 
with a band pattern similar to the $P$. falciparum DNA positive control (Fig. 4A; lane 18), were considered positives. This positive pattern was observed in 24 samples (Fig. 4A; lanes 1, 2, 5, 6, 7, 8, 9, 10, 12, 13, 14; Fig. 4B; lanes 2, 4, 5, 7, 9, 10, $11,12,13,14,15,16,17)$. The results showed the specific vertebrate's rDNA band of 126 bp in all the samples, indicating that there is no inhibition of the Taq polimerase by the anticoagulants used.
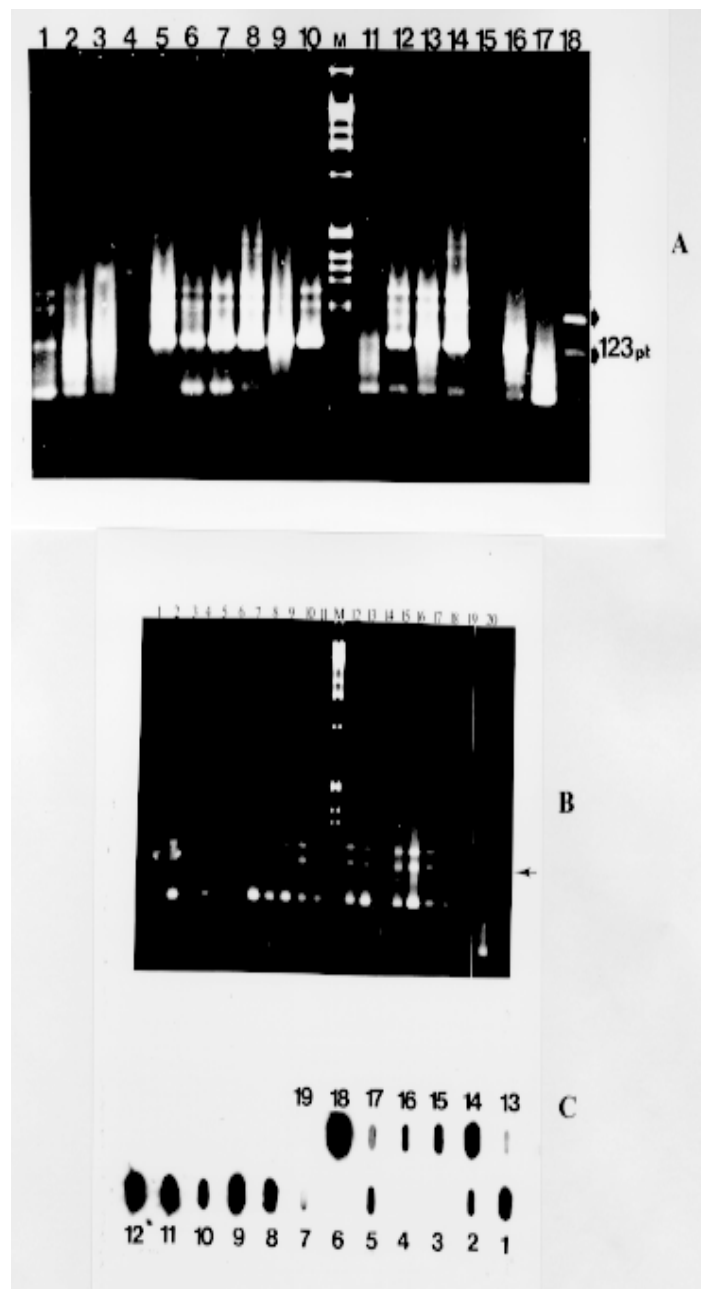

Fig. 4: PCR on human samples, PCR I system. Electrophoresis in $2 \%$ agarose gel of amplified products by PCR I pf-21. A: lanes 1 to 15 , human samples 1 to 15 ; lane 16, negative control with human DNA; lane 17, negative control no DNA; lane 18, positive control with purified Plasmodium falciparum DNA. B: lanes 1 to 17 are human samples 16 to 32 ; lane 18 , positive control with purified $P$. falciparum DNA; lane 19, negative control with human DNA; lane 20, negative control no DNA; M, $1 \mathrm{~Kb}$ ladder. C: slot blot hybridization of amplified products by PCR I pf-21 on human samples 16 to 32 against the pf-21 primer amplified product, labeled with digoxigenin. Exposition time: $30 \mathrm{~min}$. Slots 1 to 17 are human samples 16 to 32 ; slot 18 , positive control with purified $P$. falciparum DNA; slot 19, negative control with human DNA.
Slot-blot hybridization with PCR I pf-21 probe - Fig. 4C shows the slot-blot results of PCR amplifications with PCR I system on human samples. A positive signal was observed in slots $1,2,5,8,9$, $10,11,12,14,15,16$, and 17.

DNA amplification fingerprint $(D A F)$ of $P$. falciparum - Six of the 12 Amazonian Brazilian isolates were amplified by PCR I. Fig. 5 shows a different and specific polymorphic fingerprint for each isolate, within the range of $200 \mathrm{bp}$ and $3 \mathrm{~Kb}$. This method could be used as a molecular marker for genetic diversity studies in population genetic.

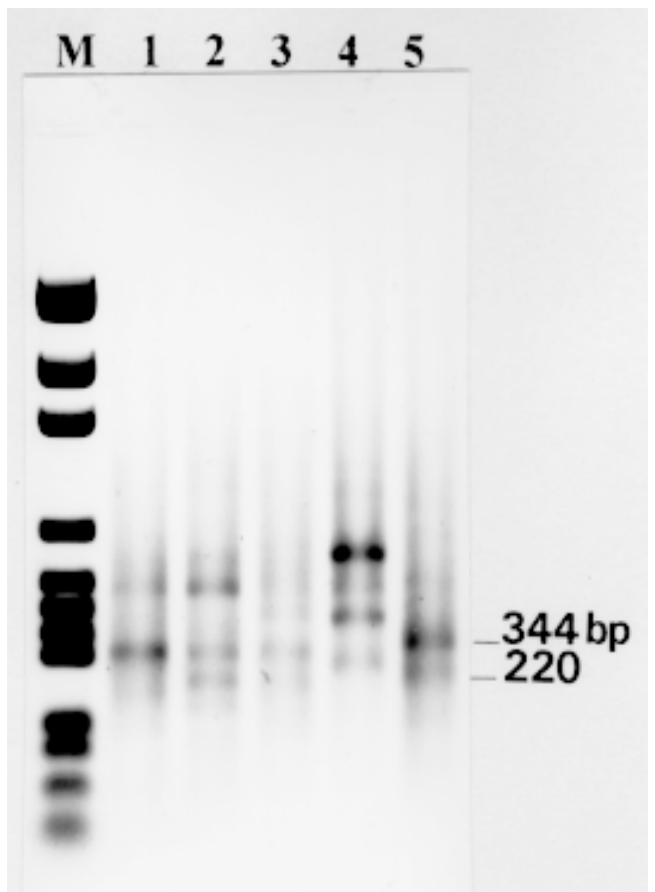

Fig. 5: DAF of Plasmodium falciparum isolates from Brazil and Colombia. Electrophoresis in $2 \%$ agarose gel of amplified products by PCR I pf-21. Brazilian isolates: 1 - 608; 2 -365; 3 51; 4 - 54 and Colombian isolate: 5; M - PGEM molecular weight marker.

Microscopic diagnostic - Table I shows the comparative results of both microscopic readings (100 and 200 fields with immersion lens) from patients blood samples. Detection level was clearly improved when the number of fields was increased. Taking into account this improvement in the microscopic exam sensitivity, we used the 200 fields reading to compare the PCR and hybridization systems. The comparative results of the PCR I, PCR III and microscopy are presented in Table II. Table III illustrates the results of 16 samples derived from the PCR (I) pf-21 test coupled to a hybridization assay, in comparison with the microscopic diagnosis. 


\section{DISCUSSION}

The current diagnosis of human malaria is achieved by microscopic examination of Giemsa stained blood smears. Although well adapted to the field situation, this methodology is not practical in terms of time and labor involved when large number of samples are required for epidemiological studies. The availability of DNA derived techniques for diagnosis of infectious agents with high specificity and sensitivity has represented an attractive alternative. Several groups have identified species specific repetitive sequences in the genome of $P$. falciparum (Franzen et al. 1984, Oquendo et al. 1986, Barker et al. 1986, McLaughlin et al. 1987) and derived DNA probes in an attempt to improve diagnosis. The highly repeated subtelomeric rep-20 sequence has been target of DNA probes as well as PCR diagnostic assays (Barker

TABLE I

Comparative detection levels of two microscopic readings. Tumeremo Bolívar State, Venezuela 1993-94

\begin{tabular}{|c|c|c|c|c|}
\hline \multirow{2}{*}{$\begin{array}{l}\text { Parasite } \\
\text { species }\end{array}$} & \multicolumn{2}{|c|}{100 field examined } & \multicolumn{2}{|c|}{200 field examined } \\
\hline & Samples No. & $\%$ & Samples No. & $\%$ \\
\hline \multicolumn{5}{|l|}{ Plasmodium } \\
\hline falciparum & 7 & 24 & 11 & 38 \\
\hline P. vivax & 7 & 24 & 6 & 21 \\
\hline Mixed infection & on & - & 2 & 7 \\
\hline Negatives & 15 & 52 & 10 & 34 \\
\hline Total & 29 & 100 & 29 & 100 \\
\hline
\end{tabular}

et al. 1992). This late approach has increased the detection level but has not significantly surpassed the microscopy diagnosis probably due to selfcomplementation between the oligonucleotides used.

Exploiting the genomic organization of the pf21 repeat, we have designed a PCR assay for $P$. falciparum based on a single consensus primer that coupled to non-radioactive hybridization, can be applied to the epidemiological diagnosis of $P$. falciparum with significant improvement over the microscopic analysis.

In order to improve the performance of the diagnostic PCR reaction it was necessary to optimize the protocol for blood sample preparation. The direct treatment of blood with chelex-100 Fe was adopted over the proteinase $\mathrm{K}$ incubation and sample preservation on filter paper. Consistent amplification of patient samples was obtained independently of the treatment with anticoagulants, as demonstrated by the vertebrate rDNA PCR assay.

We applied the PCR I system to 32 samples of malaria patients with moderate and low parasitemia. As a reference PCR, we used the PCR III system targeted on moderately repetitive sequences (Fucharoen et al. 1988, Tirasophon et al. 1991) that amplifies an unique band of $206 \mathrm{bp}$. The sensitivity of these DNA amplification assays was compared to the improved microscopic reading of 200 fields. This more extended examination of the slide increases the positive diagnosis of $P$. falciparum from $24 \%$ in 100 fields examined to $38 \%$ (Table

TABLE II

Comparative detection levels between PCR I, PCR III and microscopy. Tumeremo Bolívar State, Venezuela 1993-94

\begin{tabular}{|c|c|c|c|c|c|c|}
\hline \multirow{2}{*}{$\begin{array}{l}\text { Parasite } \\
\text { species }\end{array}$} & \multicolumn{2}{|c|}{ PCR I } & \multicolumn{2}{|c|}{ PCR III } & \multicolumn{2}{|c|}{ Microscopy } \\
\hline & No. samples & $\%$ & No. samples & $\%$ & No. samples & $\%$ \\
\hline Plasmodium falciparum & 19 & 66 & 11 & 38 & 11 & 38 \\
\hline P. vivax & - & - & - & - & 6 & 21 \\
\hline Mixed infection & 5 & 17 & 5 & 17 & 2 & 7 \\
\hline Negatives & 5 & 17 & 13 & 45 & 10 & 34 \\
\hline Total & 29 & 100 & 29 & 100 & 29 & 100 \\
\hline
\end{tabular}

\section{TABLE III}

Comparative detection levels between PCR I coupled to an hybridization assay and microscopy. Tumeremo Bolívar State, Venezuela 1993-94

\begin{tabular}{|c|c|c|c|c|c|c|}
\hline \multirow{2}{*}{$\begin{array}{l}\text { Parasite } \\
\text { species }\end{array}$} & \multicolumn{2}{|c|}{ PCR I } & \multicolumn{2}{|c|}{ PCR III } & \multicolumn{2}{|c|}{ Microscopy } \\
\hline & No. samples & $\%$ & No. samples & $\%$ & No. samples & $\%$ \\
\hline Plasmodium falciparum & 12 & 75 & 12 & 75 & 7 & 44 \\
\hline P. vivax & - & - & - & - & 2 & 12 \\
\hline Mixed infection & 1 & 6 & 2 & 12 & - & - \\
\hline Negatives & 3 & 19 & 2 & 13 & 7 & 44 \\
\hline Total & 16 & 100 & 16 & 100 & 16 & 100 \\
\hline
\end{tabular}


I). Overall, examining the slides at 200 fields favored the diagnosis of mixed infections and the detection of low parasitemia over the 100 field's routine methodology.

Three of the 32 samples showed inhibition of the PCR reaction as evidenced by the absence of the 126 bp product of the vertebrate rDNA PCR assay, and were not include in the comparison analysis. The summary of the results from the 29 patients analyzed by microscopic examination and PCR systems I and III are shown in Table II. The detection ratio of the PCR I system in relation to both the PCR III system and the microscopic examination was 1.7:1. Five of the six diagnosed $P$. vivax infections where detected positive for $P$. falciparum by both PCR I and III systems, increasing the detection of mixed infections more than two fold.

When the PCR I analysis was coupled to hybridization (Fig. 4C) and these results were compared with the microscopic exam (Table III), a similar detection ratio of 1.7:1, with a higher sensitivity for the PCR was observed. The two reported cases of $P$. vivax infection were confirmed positive to $P$. falciparum by hybridization. In general the PCR I system had a higher detection level than both the PCR III system and the 200 field microscopic examination. This increment in the detection of P. falciparum infections is significant when sub-patent parasitemia and mixed infections are not detected by the traditional method.

Additionally, the single oligonucleotide amplification produces a DNA fingerprint specific for P. falciparum isolates of immediate application to population genetic studies. It was possible to observe a pattern of reproducible bands, specifically a band of $344 \mathrm{bp}$ for the P. falciparum isolate from Colombia (Fig. 1A; lane 1, 2; Fig. 5; lane 5). The rep-20 repeat is found in the subtelomeric regions of $P$. falciparum chromosomes (Triglia et al. 1992). It is in this region where chromosome rearrangements responsible for chromosomic size changes observed is postulated to occur. The origin of these size changes is not well understood, but it is attributed to genetic exchange during the different types of cellular division (meiosis-mitosis). The possibility of obtaining an amplification pattern of these regions specific for each isolate (as the result of its chromosomic arrangement), would probably permit to follow in an epidemiological way the different circulating isolates, and the relationship of these DNA amplification fingerprints (DAFs) with other important characters, such as drug resistance and virulence.

In the group of patients studied, it was possible to distinguish at least three DAF variation patterns in the isolates circulating in the zone (Fig. 4A; lanes $1,2,8)$. A totally different pattern was observed in the positive control DNA from Colombia strain (Fig. 4A; lane 18).

These results constitute an important tool in the epidemiology of $P$. falciparum malaria. This approach will allow the analysis of large number of samples for diagnosis, detecting mixed infections and low parasitemia. Concomitantly, circulating isolates can be identified trough specific DAF for P. falciparum. We propose the combined use of this polymorphism detection analysis with other similar assays (RAPD, isoenzymes, and micro-satellites) that detect population changes, to further evaluate its discrimination capabilities in identifying different isolates circulating in endemic areas.

\section{ACKNOWLEDGMENTS}

To the patients that voluntarily accepted to participate in this study. To Dr Alejandro Caraballo and all the workers in the malaria diagnostic post of the Venezuelan Malaria Program in Tumeremo, Bolívar State, for helping in the sample collection stage. To Dr Marcelo Mazzarri and Dr Alexis Rodriguez for their helpful support. To Dr Moises Wasserman, Dr Hernán Del Portillo and Dr Erlinda Sánchez for providing the reference strain DNAs.

\section{REFERENCES}

Barker R, Banchongaksorn T, Courval J, Suwonkerd W, Rimwungtragoon K, Wirth D 1992. A simple method to detect Plasmodium falciparum directly from blood samples, using the polymerase chain reaction. Am J Trop Med Hyg 46: 416-426.

Barker R, Suebsaeng L, Rooney W, Alecrim G, Dourado H, Wirth D 1986. Specific DNA probe for the diagnosis of Plasmodium falciparum malaria. Science 231: 1434-1436.

Buesing M, Guerry P, Diesanti C 1987. An oligonucleotide probe for detecting $P$. falciparum: an analysis of clinical specimens from six countries. J Infect Dis 155: 1315-1318.

Davis L, Dibner M, Battey J 1986. Basic Methods in Molecular Biology. Elsevier, N.Y.

Franzen L, Shabo R, Perlmann H, Wigzell H, Westin G, Aslund L, Persson T, Pettersson U 1984. Analysis of clinical specimens by hybridization with probe containing repetitive DNA from Plasmodium falciparum. A novel approach malaria diagnosis. Lancet 1: 525-527.

Fucharoen S, Tirawanchai N, Wilairat P, Panyim S, Thaithong S 1988. Differentiation of Plasmodium falciparum clones by means of a repetitive DNA probe. Trans R Soc Trop Med Hyg 82: 209-211.

Lal A, Changkasin S, Holingdadi M, McCutchan T 1989. Ribosomal RNA-based diagnosis of $P$. falciparum malaria. Mol Biochem Parasitol 36: 67-72.

Lanar D, McLaughlin G, Wirth D, Barker R, Zolg J, Chulay J 1989. Comparison of thick films, in vitro culture and DNA hybridization probes for detecting P. falciparum malaria. Am J Trop Med Hyg 40: 3-6. 
Maniatis T, Fritsch E, Sambrook I 1982. Molecular Cloning: A Laboratory Manual, Cold Spring Harbor Laboratory.

McLaughlin G, Breman J, Collins W, Schwartz I, Brandling-Bennet A, Sulzer A, Skinner J, Ruth J, Andrysiak P, Kasaje D, Campbell G 1987. Assessment of a synthetic DNA probe for Plasmodium falciparum in African blood specimens. Am J Trop Med Hyg 37: 27-36.

Oquendo P, Goman M, Mackay M, Langsley G, Walliker D, Scaife J 1986. Characterization of repetitive DNA sequence from the malaria parasite, Plasmodium falciparum. Mol Biochem Parasitol 18: 89-101.

Premoli-de-Percoco G, Pinto-Cisternas J, Ramirez JL, Galindo I 1993. Focal epithelial hiperplasia: Humanpapillomavirus induced disease with a genetic predisposition in Venezuela family. Hum Gent 91: 386388.

Tirasophon W, Ponglikitmongkol M, Wilariat P, Boonsaeng N, Panyim S 1991. A novel detection of a single Plasmodium falciparum in infected blood. Biochem Biophys Res Comm 175: 179-184.
Tirasophon W, Rajkulchai P, Ponglikitmongkol M, Wilairat P, Boonsaeng V, Panyim S 1994. A highly sensitive, rapid and simple polymerase chain reaction-based method to detect human malaria (Plasmodium falciparum and Plasmodium vivax) in blood samples. Am J Trop Med Hyg 51: 308-313.

Triglia T, Wellems T, Kemp D 1992. Towards a highresolution map of the Plasmodium falciparum genome. Parasitol Today 8: 225-229.

Wathers AP, McCutchan T 1989. Rapid sensitivity diagnosis of malaria based on ribosomal RNA. Lancet 8651: 1343-1346.

WHO - World Health Organization 1997. World malaria situation in 1994. Weekly Epidemiol Record, Geneva 72: 36-269.

Wooden J, Kyes S, Sibley C 1993. PCR and strain identification in Plasmodium falciparum. Parasitol Today 9: 303-305.

Zolg J, Andrade L, Scott E 1987. Detection of Plasmodium falciparum DNA using repetitive DNA clones as species specific probes. Mol Biochem Parasitol 22: $145-151$. 